\title{
A narrativa cinematográfica inserida nos fenômenos midiáticos da contemporaneidade: 0 cinema no videoclipe e vice-versa
}

DOI: 10.1590/1809-58442018314

\author{
Cristiane do Rocio Wosniak ${ }^{1}$ \\ https://orcid.org/0000-0002-7234-2638
}

${ }^{1}$ (Universidade Estadual do Paraná, Campus de Curitiba II - Faculdade de Artes do Paraná, Programa de Mestrado Acadêmico em Cinema e Artes do Vídeo, Curitiba - PR, Brasil).

OLIVA, R. Interconexões de poéticas audiovisuais: transcineclipe, transclipecine e hiperestilização. Curitiba: Appris, 2017.

O livro Interconexões de poéticas audiovisuais: transcineclipe, transclipecine e hiperestilização, de Rodrigo Oliva, lançado em 2017 pela Editora Appris, configura-se como uma publicação resultante de sua tese de doutorado.

De forma criativa, poética e fluida, sem, contudo, se afastar do rigor metodológico e científico, conferidos pela intensa pesquisa bibliográfica aliada à análise fílmica, o autor constrói, ao longo de 167 páginas, um elo para discussões e debates sobre a comunicação audiovisual na

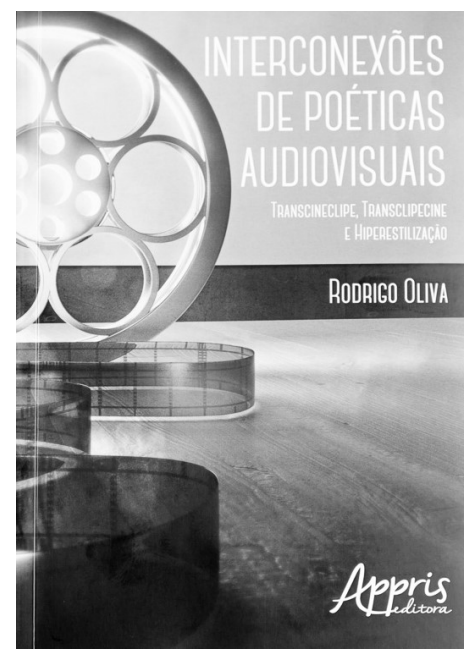
contemporaneidade.

É a partir das marcas constitutivas de uma narrativa audiovisual rizomática que Oliva (2017) traça um paralelo comparativo entre as interferências estéticas cinematográficas que povoam o videoclipe e vice-versa. Neste seguimento, o autor desenvolve dois argumentos que se desmembram e se articulam na definição de sua tese: o conceito de transcineclipe (aspectos da linguagem do videoclipe que contaminam a narrativa de alguns filmes) e transclipecine (aspectos característicos da linguagem cinematográfica presentes nos videoclipes contemporâneos).

A obra divide-se em quatro capítulos que se interconectam no compromisso de apresentar argumentos sólidos para comprovar a convergência da linguagem do videoclipe nos filmes de narrativas clássicas, bem como apontar desdobramentos da construção destas narrativas fílmicas em videoclipes.

A definição do corpus analisado na obra destaca os cineastas estadunidenses David Fincher, Michel Gondry e Spike Jonze, "por terem um contato direto com o cinema e o 
videoclipe e atuarem em fluxo em ambas as linguagens.” (OLIVA, 2017, p.23). Os jovens cineastas franco-canadenses, Xavier Dolan e Jean Marc-Vallée, por sua vez, são trazidos à cena como exemplos da aplicabilidade do argumento desenvolvido por Oliva (2017).

Na estruturação do caminho metodológico, o autor organiza os capítulos de forma a enfatizar, de forma coerente e sucinta, o percurso do pensamento que tangencia a criação de suas premissas.

No primeiro capítulo, "Mapeando os Conceitos no Tempo e no Espaço”, como o próprio título já evidencia, o contexto histórico e estético do cinema e das artes do vídeo é explorado e o ponto de conexão entre ambas as artes ou formas de comunicação é traçado a partir de proposições similares: entreimagens, convergência, dialogismo e estética da hipervenção, esta última transferida à cena textual por meio da teoria desenvolvida por sua orientadora, a Profa. Dra. Denize Araújo (PPGCOM/UTP).

No segundo capítulo, intitulado “O Transcineclipe”, três construções teóricas se manifestam para dar corpo à hipótese/conceito: a passagem, a paisagem e a narrativa transcineclípicas.

Segundo Oliva (2017), a passagem discute “a questão que envolve o movimento, o ritmo e as ligações estabelecidas com a montagem fílmica” (p.34), enquanto a paisagem compreende as correlações diretas com "a imagem audiovisual e os recursos estéticos fílmicos que podem caracterizar o conceito a partir de algumas estruturas do código audiovisual” (p.34).

O conceito de transcineclipe é abordado inteiramente no terceiro capítulo, onde também se descortina uma nova perspectiva teórica advinda das narrativas dilatadas em seus possíveis ecos espaciais e temporais.

Salienta-se que a narrativa dilatada adentra à discussão por meio dos aportes da coorientação do pesquisador e professor José Bidarra, efetuada na Universidade Aberta de Lisboa, em Portugal, o que contribuiu, segundo o autor, para a ampliação do seu olhar sobre a temática investigada.

No último capítulo, denominado “Por uma Estética da Hiperestilização”, evidenciamse as marcas dos processos transcineclipe e transclipecine, que se revelam, por meio da análise fílmica de filmes e videoclipes contemporâneos, enquanto presenças intensivas da estética da hiperestilização em novas reinvenções audiovisuais híbridas.

Ao longo do livro, que parte de um recorte audiovisual bastante inusitado e pouco explorado no universo acadêmico, constata-se a relevância do objeto e do tema investigado para a área das Artes e das Comunicações, pelo esmero, originalidade e estilo rizomático no que concerne à articulação de hipóteses e argumentos somados às passagens oníricas e poéticas da escrita do texto.

Teorias e estudos da Comunicação e das Artes do Vídeo são acionados, em suas especificidades, para fundamentar as análises fílmicas e videográficas comparativas que se debruçam sobre 45 filmes, 33 videoclipes e uma série televisiva. Neste sentido, o ancoramento teórico dá ênfase a autores como Agambem, Bellour, Bordwell, Canclini, 
Chion, Deleuze, Dubois, Jenkins, Lipovetsky e Manovich, além dos brasileiros Ismail Xavier e Arlindo Machado.

Oliva (2017) encerra a obra defendendo a clara opção por um corpus múltiplo de materiais audiovisuais que pudesse dialogar e exemplificar o trânsito entre as linguagens estudadas “absorvendo conceitos e os fazendo interagir” (p.151).

Frutos da contemporaneidade, as noções destacadas no livro carregam, ao mesmo tempo, uma matriz midiática e uma artística em perene dissolução de fronteiras, o que caracteriza os principais pontos referenciais da obra que, em momento algum segue um padrão rígido de análise ou objetos de estudos monológicos e centralizadores. Ao invés disso, o autor, cuja carreira acadêmica perpassa a pesquisa e a docência, pensa a escrita para os seus alunos, ou para o consumo de uma espécie de leitor ideal, como ele mesmo aponta: "gostaria que minha tese fosse lida e entendida como algo a ser aplicável, pensado, desconstruído e reconstruído” (OLIVA, 2017, p.158).

Finalmente, cabe ressaltar que, em Interconexões de poéticas audiovisuais: transcineclipe, transclipecine e hiperestilização, Oliva (2017) estabelece uma insólita interlocução entre as linguagens do cinema e do videoclipe, pensando-as como entidades maleáveis em um regime de interconexões híbridas, e, acima de tudo, como fenômenos comunicacionais.

\section{Referências}

OLIVA, R. Interconexões de poéticas audiovisuais: transcineclipe, transclipecine e hiperestilização. Curitiba: Appris, 2017.

\section{Cristiane do Rocio Wosniak}

Mestre e doutora em Comunicação e Linguagens (linha de Estudos de Cinema e Audiovisual) pela Universidade Tuiutí do Paraná (UTP). Docente titular do programa de Mestrado Acadêmico em Cinema e Artes do Vídeo e docente adjunta do curso de Bacharelado em Cinema e Audiovisual na Universidade Estadual do Paraná - campus de Curitiba II/Faculdade de Artes do Paraná (UnesparPR). E-mail: cristiane_wosniak@yahoo.com.br.

Recebido em: 05.06.2018

Aceito em: 09.11.2018

Este artigo é publicado em acesso aberto (Open Access) sob a licença Creative Commons Attribution Non-Commercial (CC-BY-NC), que permite uso, distribuição e reprodução em qualquer meio, sem restrições, desde que sem fins comerciais e que o trabalho original seja corretamente citado.

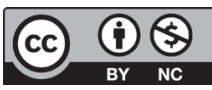

